\title{
A politics of forgiveness? Engaging the ontological and the structural in the dialogical theology of John de Gruchy
}

\author{
Forster, Dion \\ Stellenbosch University, Stellenbosch, South Africa \\ dionforster@sun.ac.za
}

\begin{abstract}
Forgiveness is a deeply contested theological notion in contemporary South African theology and society. The same could be said for South African theologies of reconciliation, of which forgiveness is considered to be a part. Some claim that these concepts have been weakened, abused, and corrupted. In particular, there are doubts whether forgiveness holds any theological or social value at present. John de Gruchy has devoted a great deal of time and effort to developing a theologically subtle, and politically robust, understanding of forgiveness that links justice and reconciliation. This article will consider how John de Gruchy's dialogical theology, which takes account of both the ontological and the structural aspects of forgiveness, facilitates an understanding of political forgiveness that can address some of the critiques of this notion in contemporary South African theologies.
\end{abstract}

\section{Keywords}

John de Gruchy; Systematic theology; theological ethics; Public Theology; South Africa; forgiveness; Political Theology

\section{Introduction}

This essay intends to honour the dialogical theological approach of John de Gruchy by focussing on a particular aspect of his contribution - namely his concept of "political forgiveness". ${ }^{1}$ De Gruchy characterises political

1 It is important to understand that forgiveness and reconciliation are not synonymous. We shall also not treat them as such in this essay. In John de Gruchy's understanding, forgiveness is a necessary component on the journey towards reconciliation (cf., De Gruchy, 2002: 31-38, 171-181). 
forgiveness as, "a risk taken on the basis of mature insight and political acumen and one that displays moral courage" (De Gruchy, 2002: 173). We shall return to this in detail in a later section of the essay.

The intention of this engagement is twofold. First, it aims to revisit the importance of developing robust, nuanced, and even contested understandings of forgiveness that are capable of making a constructive theological contribution in situations of brokenness and offence. It will be argued that Christians cannot 'give up' on the language of forgiveness since forgiveness is central to our faith. It is as aspect of God's nature, and also an expectation for true community. Yet, it will also be argued that jaundiced and ill-considered conceptualisations of forgiveness need to be challenged and reconsidered. Second, this essay aims to show how John de Gruchy's dialogical theological approach is capable of holding a creative tension between faith-filled theological conviction and contemporary (and historical) concerns - these will be characterised as the "ontological" and the "structural"3 aspects of De Gruchy's theology. When these two characteristics are brought together, the outcome is a more robust theological understanding of the necessity, and conceptualisation, of notions and processes, of forgiveness that honour the convictions of the Christian theological tradition (ontologically), while also taking concrete social and historical realities (structural elements) seriously.

The reader may consider that such a contribution is as necessary today as it ever has been. South Africa, the country of John de Gruchy's birth, ${ }^{4}$ and the context of so much of his writing, is currently facing a painful and dangerous period in its young and fragile democracy. While the country

2 Within the context of this essay, ontology refers to "the nature of Being" in a similar tradition to Heidegger's understanding and use of the term (Dyrness \& Kärkkäinen 2009: 381, 725-727). In other words, the ontological is an expression of what truly is, the true, the eternal, (the ground of Being, Being itself).

3 The notion of the structural, as employed in this essay, refers to the complex sets of arrangements and of relations between persons, institutions, histories and lived realities that constitute and form lived realities (Dyrness \& Kärkkäinen 2009: 779, 127).

4 Please see John de Gruchy's autobiography, I Have Come a Long Way for information on his person and life (De Gruchy 2016). Please see, A theological odyssey: My life in writing for a reflective overview of John de Gruchy's theological emphases (De Gruchy 2014). 
remains overwhelmingly Christian, ${ }^{5}$ there is a growing concern about toxic and destructive Christianities ${ }^{6}$ that are growing exponentially in a context that is ravaged by mass poverty, extreme economic inequality, ongoing racism and the re-emergence of shallow identity politics (cf., Hofmeyr \& Govender, 2015; Mbembe, 2015). High levels of corruption and low levels of basic service delivery have caused a deep distrust in the leaders of the anti-apartheid liberation struggle, in whom so much hope was vested (cf., Forster 2011: 71-96, 2015: 1-10; Kotzé 2016: 437-448; Kotzé \& GarciaRivero 2017: 1-17; Vincent 2011: 1-14). Moreover, the ecumenical Church, which is so important in South African social life, seems ill equipped to provide moral and political guidance at this crucial moment.

Elsewhere in the world Christianity is playing an ambivalent role in the shaping of public opinion which is having a concerning impact on the formation of public life. Consider the contribution of Christian Nationalism in Victor Orban's Hungary (cf., Brubaker 2017: 1191-1226; Fekete 2016: 39-53; Tartakoff 2012: 360-366; Walker 2019), or the role of right wing evangelicalism in Donald Trump's America (Cherkaoui 2017; Forster 2019a: 267-275). These are just two examples among many that could be cited to illustrate the ambiguous role that Christianity, and poorly developed political theologies, are playing in countries across the world.

Contemporary societies, and contemporary Christianities, require theologies that are capable of holding to the historical theological convictions of the Christian faith in tension with social, political, ecological, and economic realities. In what follows we shall see how John de Gruchy's notion of "political forgiveness" provides an example of such a theology and such a theological approach (De Gruchy 2002: 173).

5 South Africa remains a deeply religious nation. The most recent survey of the South African population conducted by StatsSA was done in 2013. This survey shows that $84.2 \%$ of South Africa's citizens self-identified as Christians (General Household Survey 2013, 2014; Schoeman 2017: 3).

6 For a discussion on the re-emergence of state supporting theological and religious populism please see, (Forster, 2019b). For some discussion on why South African Christians seem to be turning to prosperity religious movements that perpetrate abusive practices ranging from sexual abuse, physical abuse to economic abuse, please see, (Forster \& Pondani 2019; Van Wyk 2014; Van Wyk 2019) 


\section{A prolegomenon on John de Gruchy's dialogical theology}

John de Gruchy is one of South Africa's pre-eminent theologians. ${ }^{7} \mathrm{His}$ prolific theological contribution has shaped the thinking of scores of theologians in the academy, Church and society at large. A great deal of de Gruchy's writing engages issues of contemporary public concern in Southern Africa. However, his theology is not parochial. While it is deeply contextual, it is also grounded within the ecumenical Reformed theological tradition. As a result, his work has been widely received and engaged by theologians from the Americas, Europe, Asia, Africa, and Oceania (Clements 2016: 153-155).

A 2002 festschrift in his honour aptly describes his work as "theology in dialogue" (Holness \& Wüstenberg 2002: xiii). His “theology in dialogue" has a developed through engagements with theological aesthetics (cf., Everett \& De Gruchy 2014; De Gruchy, 2001, 2011a), the natural sciences (De Gruchy, 2013a), and an invaluable reformed theological dialogue with political life and thought (De Gruchy 1986, 2005a; De Gruchy \& Villa-Vicencio 1985; Holness \& Wüstenberg 2002: xiii). Themes of justice run throughout his theological dialogues and form a 'golden thread' throughout his work (De Gruchy 2014: 94-112).

Three particular emphases in De Gruchy's reformed theological engagement with justice bear special mention in relation to this project. ${ }^{8}$ First, he is a Reformed theologian who has been deeply and significantly informed by this tradition. The Reformed tradition influences not only his approach to theology, but also his primary conversation partners. As such he frequently engages John Calvin, Calvinism and contemporary Reformed theologies

7 Prof de Gruchy is widely regarded as one of the most important contemporary South African theologians. Of course, since he is humble, he would underplay his contribution. However, he is an 'A' rated researcher with the South African National Research Foundation (NRF). This is the highest research rating that a South Africa scholar can be awarded ("UCT's De Gruchy honoured", 2004). Moreover, he is regarded as one of the global thought leaders in the field "public theology" "political theology" and "reconciliation" (See the essays De Gruchy's contribution to faith and public life, and faith and political life, in Holness \& Wüstenberg 2002: 81-285; Koopman 2003: 16-18; Smit 2007: 442, 444-445). All of these have a direct bearing on the focus of this article.

8 I shall only highlight the major publications (monographs and collections of essays) in relation to each of these three themes or topics. Of course, there are numerous scholarly articles on each of these topics that the reader could easily access via an internet search of a scholarly database. 
and theologians in his work (De Gruchy 1991, 2013b, 2014: 71-73, 90-93; De Gruchy \& Villa-Vicencio 1985). Yet, it is notable that his work in theological aesthetics and Christian humanism have brought him into conversation with notable Catholic theologians (such as Hans Urs von Balthassar) and Orthodox thinkers (such as his work on Icons, and his engagements with Patristic theologies in relation to Christian humanism) (De Gruchy 2014: 129-131, 148-149). Second, he has a particular interest in the work of the German Lutheran theologian, Dietrich Bonhoeffer (De Gruchy 1984, 1997, 1999, 2005b). Bonhoeffer's ecclesiology, and in particular his ethics, played a crucial and significant role in shaping De Gruchy's understanding of Christianity, the Church, and justice in society (De Gruchy 2014: 108-113, 136-141) Third, he has developed a rich corpus of theological reflection on Christian humanism (De Gruchy 2006, 2011b, 2013b). His understanding of Christian anthropology informed not only his views on what humanness entails (ethically), but also to what end humans are created as bearers of God's image, and co-labourer's with God towards an eschatological hope for all of creation (De Gruchy 2014: 132-149).

I would venture that these three foci tie together his most recent theological work, and also chart a progression in his theological development. This is evidenced in the manner in which De Gruchy himself outlines his theological journey in eight movements in the volume: A theological odyssey: My life in writing (De Gruchy 2014). While the intention of that volume is not necessarily to trace a single historical trajectory to his developing thought, it does offer something of a guideline to how his thinking has developed in relation to his own biography and the events in history that shaped him personally, theologically and politically. I found it particularly helpful to read A theological odyssey, alongside his autobiography, I Have Come a Long Way (De Gruchy 2016).

What is pertinent for the sake of this essay is that one is able to discern the dialogical engagement between De Gruchy's reading of Reformed Christian theologies (what I am regarding as his quest for the "ontological") with particular historical events, persons, concepts, or schools of thought (what is presented as the contextual, or the "structural"). ${ }^{9}$

9 Please refer to footnotes 2 and 3 for a discussion of how these concepts are used in this essay. 


\section{Should we give up on "forgiveness"? Challenges from contemporary South Africa}

John de Gruchy has devoted a significant proportion of his theological effort to addressing the concerns for reconciliation and justice in South Africa. He embarked on this journey during the dark and difficult days of theologically sanctioned apartheid in South Africa. He spent a great deal of time and energy unmasking the heresy of theologically sanctioned white supremacy and the political system that kept this evil in place (cf., De Gruchy 1986, 2005a; De Gruchy \& Villa-Vicencio 1983, 1985). He clearly understood that the structural systems of injustice that operated in the apartheid state (the "hardware" of oppression), were held in place, and indeed emanated from, belief systems and values (the "software") that theologians and the Church needed to challenge and reframe. And so, he engaged those structures, and the beliefs upon which they were built, in his theological thinking. In doing so, he aimed to "help us and future generations better understand the challenges facing the church in South Africa" (De Gruchy 2014: 15). In order to do this work adequately he had to maintain both a historical theological and a contextual consciousness - a dialogue between what we believe to be true, right, and wise, and what we see and experience as the reality of the world around us. In his contextual work he was careful to avoid a "simplistic treatment" and "easy generalisations" of persons, events and ideas (De Gruchy 2014: 15). This is particularly evident in his rich, textured, and patient, retelling of the history of Christianity and the Church in South Africa in The Church Struggle in South Africa (De Gruchy 2005a). In this project he recognises that Christianity and the Church is "marked by fatal compromise and courageous witness" (De Gruchy 2014: 16). Simply stated, De Gruchy's work helps us to recognise that "the complexity is in the detail", and that this complexity frequently operates at the intersections of well intentioned, and sometimes even long held, beliefs (the "ontological"), that are misshapen, forgotten, discarded or manipulated in a given context in time and place (the "structural").

Therefore, it is no surprise that De Gruchy was already writing about justice and reconciliation long before the end of political apartheid in 1994. In fact, De Gruchy suggests that the dual emphases of "justice" and "reconciliation" are at the heart of the Church's struggle against apartheid (De Gruchy 2014: 97). In his essay The struggle for justice and the ministry of 
reconciliation he claims that true liberation, and true justice, would require true reconciliation (De Gruchy 1988: 166-180). He would eventually develop, and unpack, these ideas in detail in his book Reconciliation: Restoring Justice (De Gruchy 2002). De Gruchy quotes Desmond Tutu, in summarising his understanding of the relationship between reconciliation and justice (cf., the discussion in De Gruchy 2002: 173-174). Tutu said that it "is ultimately in our own best interest to become forgiving, repentant, reconciling and reconciled people, because without forgiveness, without reconciliation we have no future." (Tutu, 2012: 127).

Yet, this was not project that was without peril! De Gruchy acknowledges that reconciliation is a deeply contested subject (cf., De Gruchy 1988: 166-180, 2002: 31-37). It requires sensitivity, courage, grace, sacrifice and patience; nonetheless he remained committed to the notion of reconciliation coupled to justice, employing the theological metaphors of "covenanting" and "hope" to "restore justice" (De Gruchy 2002: 181-213).

The sad reality is that notions and processes of reconciliation have fallen out of favour in contemporary South African theologies. There is a deep suspicion of theologians who employ the language of reconciliation and forgiveness, and there are significant critiques of those who have used it in the past. In large measure this is linked to two concerns. First, there are those persons who highlight the perceived failures of the Truth and Reconciliation Commission (TRC) (cf., Bundy 2000: 9-20; Forster, 2016; Peires 2009: 178-186; Shore 2016; Steyn 2001: 85-103; Van der Merwe \& Chapman 2008)"event-place":"Johannesburg","abstract":"The legacy of anti-apartheid activists no longer has currency for many of today's youth. They believe that they have been failed by the older generation of political leaders, including Nelson Mandela." This book examines the ambiguous role that Christianity played in South Africa's Truth and Reconciliation Commission (TRC. The second set of concerns focus on the tension between calls for reconciliation and the ongoing realities of injustice in South Africa. This sentiment is evidenced in the 2015 Institute for Justice and Reconciliation (IJR) report on reconciliation, which notes that:

While most South Africans agree that the creation of a united, reconciled nation remains a worthy objective to pursue, the country remains afflicted by its historical divisions. The majority feels that 
race relations have either stayed the same or deteriorated since the country's political transition in 1994 and the bulk of respondents have noted income inequality as a major source of social division. Most believe that it is impossible to achieve a reconciled society for as long as those who were disadvantaged under apartheid remain poor within the "new South Africa" (Hofmeyr \& Govender 2015: 1).

Notice that the report employs the theological language of reconciliation, saying that reconciliation (a theological concept) would be impossible "for as long as those were disadvantaged under apartheid remained poor" (Hofmeyr \& Govender 2015: 1). The ontological is questioned in light of the structural. This gets to the very heart of the matter - would God truly expect persons to be reconciled with ongoing injustice? Yet, as De Gruchy argues, it is precisely at this juncture that forgiveness becomes important (De Gruchy 2002: 173-178). How we understand forgiveness seems to be crucial to how we will structure the relationship between justice and reconciliation. Political forgiveness forms the bridge between justice and reconciliation, as we shall see below. In order to understand this, some important questions need to be asked.

Why would white South African's want forgiveness for apartheid and colonialism? Is it to deal with the "sins" of the apartheid and colonial past? Or is forgiveness intended to offer a future that is free from the necessity for reparation and restoration in the present? What would it take to be worthy of being forgiven for the historical, and ongoing, "sins" of apartheid and colonialism? Why are black South Africans so deeply distrustful of the language and concepts of forgiveness in contemporary social and political life? What is the relationship between Christianity, colonialism, and apartheid? And, can Christians give up on the notion of forgiveness, which seems so central to our faith?

Numerous South African scholars and activists have raised concerns about the manner in which forgiveness has been turned into a social and political utility by some South Africans. There are grave concerns about the narrow way in which forgiveness is understood and utilised, in this context (cf., Forster, 2018: 77-94; Gobodo-Madikizela \& Merwe 2009; Vosloo 2015a, 2012). 
This is painfully illustrated by the South African poet, Nathan Trantraal, in his poem "Fiction en enstrangement". In the poem he relates how Christians urged black South Africans to be "Christlike" after the 1994 elections. They were urged to give up the violent struggle for liberation, and simply to forgive their white perpetrators for the sins of apartheid. Trantraal casts this as a form of cheap forgiveness - forgiveness without justice. He writes that after they were urged to forgive:

Ammel het hystoe gegan

Hulle na hulle hyse langsie sea

ós na ós shacks

langs poeletjies stagnant wate

waa die gif in vergifnis

ós ammel

siek gemaak et

This cheap forgiveness made everyone, both black and white, sick. He employs a subtle play on the Afrikaans words for forgiveness and poison to do so, pointing to the "gif [poison] in vergifnis [forgiveness]" (emphasis added) (cf., "Alles het niet kom wôd deur Nathan Trantraal" 2017; Trantraal 2017).

Indeed, many of South Africa's black citizens feel that forgiveness is poisonous - it requires them to make further sacrifices for the sake of social harmony, while the perpetrators and beneficiaries of the injustices of apartheid, white South Africans, get to continue to live with their historical privilege resulting from ill-gotten gain. The social historian, Sampie Terreblanche, pointed out that white South Africans are generally more economically prosperous today than they were before the end of political apartheid (Terreblanche 2002: 55, 143, 387). In this major work - which took eight years to complete - Professor Sampie Terreblanche, a well-known Afrikaner academic of the University of Stellenbosch, provides an analysis of economic relations in South Africa. First, the book analyzes the work of numerous historians on inequality and exploitation in South Africa around a single theme: the systematic and progressive economic exploitation of indigenous people by settler groups. This synthesis is presented in a highly original, striking, and accessible way. Second, Terreblanche argues that, despite South Africa's successful transition to democracy, its society is 
as unequal today, if not more so, than ever before. In a final chapter, he argues that the current system of '"neo-liberal democratic capitalisml" is inappropriate to a developing country such as South Africa. He calls for a policy shift towards social democracy in which the state should play a more active role in alleviating poverty, redistributing wealth, and attending to social welfare. There is significant evidence that shows that income inequality is higher in 2019 than it ever was in South Africa (Baker 2019: 1-11). As the Trantraal and the IJR report note, forgiveness without social, economic and political transformation, is disingenuous - theologically speaking, we could say that there is a mismatch between the ontological expectation and the structural reality. Cheap forgiveness leads to enmity rather than reconciliation (Forster 2018: 77-79). I would venture that most theologians, including John de Gruchy, would be critical of such notions of forgiveness since they do not seem to take the structural, contextual, lived reality or individuals and communities seriously.

So, in this sense, it may not be a bad idea to give up on certain understandings of forgiveness.

The philosopher and theologian, Cornel West, was once asked how he felt about persons who were losing their faith and their trust in God. $\mathrm{He}$ responded that a certain measure of atheism is quite a good thing, since it "clears the decks" of "idolatry" (Union Theological Seminary 2016). He suggests that giving up belief in God was not such a bad thing, since the gods that many people believed in were false gods and idols that were not worthy of faith. The same could be said of "poisonous forgiveness" that has not served South Africans in the aims of justice and reconciliation. Indeed, in this regard De Gruchy noted that forgiveness can become "a tool in the manipulation of power relations, making the oppressed even more of a victim of injustice" (De Gruchy 2002: 171).

So yes, certain types of forgiveness have proven inadequate to deal with South Africa's woundedness. We must move beyond those sentimental, weak, justice avoiding - indeed, poisonous - forms of forgiveness. Yet, as was noted earlier, in a nation where religion and religious institutions and leaders remain among the most trusted sectors of society, and almost $86 \%$ of the citizens self-identify as Christian - the language of forgiveness, and the belief in this central Christian concept, cannot simply be cast aside 
(Lugo \& Cooperman 2010: 3-4; Schoeman 2017: 1-7; Winter \& Burchert 2015: 1). Moreover, orthodox Christianity cannot dispense with forgiveness altogether - soteriology is central to our faith. It stems from the nature of God and is believed to be God's eschatological intention for creation (Migliore 2004: 164-165). True forgiveness, political forgiveness, must encompass the structural reality, (namely, social, economic and political justice), as well the ontological (namely the belief that forgiveness, as more than just an economic or political transaction, is a core value for personal, spiritual and social wholeness). De Gruchy says that this "is why the ethics of forgiveness must be rooted in the message of divine forgiveness, for otherwise it oscillates 'between legalism and sentimentality'.” (De Gruchy 2002: 173).

\section{Between the prose of justice and the poetics of agape}

The South African theologian, and friend of John de Gruchy, Robert Vosloo, speaks of this delicate balance as the "prose of justice and the poetics of agape" (Vosloo 2015b: 3)" this article considers the promise that the notion of "mutual recognition" as exemplified in the later work of Paul Ricœur holds for discourse on these matters. Can the hermeneutical and mediating approach of Ricœur provide an adequate framework in order to respond to these radical challenges? In light of this question, this article discusses and ultimately affirms Ricœur's view that places mutual recognition between what he calls the prose of justice and the poetics of agápē. In addition this article draws attention to the value of symbolic gestures and an ethic of linguistic hospitality to give further texture to the plea for mutual recognition amidst experience of exclusion, conflict and violence. Vosloo argues that authentic and rigorous Christian forgiveness requires both the prose of justice (an attention to the structural) and the poetics of agape (the ontological frame of a God who is love, creates in love, and redeems for love). Such an engagement ushers in a "thicker moral language", that deepens our understanding of the meaning of the ideal (agape - truth, beauty, flourishing) and also thickens our understanding of the most desirable concrete reality (justice) (Vosloo 2015b: 3)" this article considers the promise that the notion of "mutual recognition" as exemplified in the later work of Paul Ricœur holds for discourse on these matters. Can the hermeneutical and mediating approach of Ricœur provide an adequate 
framework in order to respond to these radical challenges? In light of this question, this article discusses and ultimately affirms Ricœur's view that places mutual recognition between what he calls the prose of justice and the poetics of agape. In addition this article draws attention to the value of symbolic gestures and an ethic of linguistic hospitality to give further texture to the plea for mutual recognition amidst experience of exclusion, conflict and violence.

De Gruchy is very clear in his understanding of a political forgiveness that, the "forgiveness of God proclaimed in the gospel makes no sense at all unless understood in the light of God's judgement on sin and oppression, and God's costly gift of reconciliation.” (De Gruchy 2002: 171-172). He goes on to say that forgiveness "does not rule out anger or just punishment, and certainly does not excuse those who oppress and victimize" (De Gruchy 2002: 172). However, the ontological aspect of forgiveness as a soteriological concept, with eschatological implications, seeks to move from "justice as punishment" to "justice as restoration" (Shriver, 1995: 32). Our century has witnessed violence on an unprecedented scale, in wars that have torn deep into the fabric of national and international life. And as we can see in the recent strife in Bosnia, genocide in Rwanda, and the ongoing struggle to control nuclear weaponry, ancient enmities continue to threaten the lives of masses of human beings. As never before, the question is urgent and practical: How can nations - or ethnic groups, or races - after long, bitter struggles, learn to live side by side in peace? In An Ethic for Enemies, Donald W. Shriver, Jr., President Emeritus of Union Theological Seminary, argues that the solution lies in our capacity to forgive. Taking forgiveness out of its traditional exclusive association with personal religion and morality, Shriver urges us to recognize its importance in the secular political arena. The heart of the book examines three powerful and moving cases from recent American history--our postwar dealings with Germany, with Japan, and our continuing domestic problem with race relations - cases in which acts of forgiveness have had important political consequences. Shriver traces how postwar Germany, in its struggle to break with its political past, progressed from denial of a Nazi past, to a formal acknowledgement of the crimes of Nazi Germany, to providing material compensation for survivors of the Holocaust. He also examines the efforts of Japan and the United States, over time and across boundaries of race and culture, to forgive the 
wrongs committed by both peoples during the Pacific War. And finally he offers a fascinating discussion of the role of forgiveness in the American civil rights movement. He shows, for instance, that even Malcolm X recognized the need to move from contempt for the integrationist ideal to a more conciliatory, repentant stance toward Civil Rights leaders. Malcolm came to see that only through forgiveness could the separate voices of the African-American movement work together to achieve their goals. If mutual forgiveness was a radical thought in 1964, Shriver reminds us that it has yet to be realized in 1994. "We are a long way from ceasing to hold the sins of the ancestors against their living children," he writes. Yet in this poignant volume, we discover how, by forgiving, enemies can progress and have progressed toward peace. A timely antidote to today's political conflicts, An Ethic for Enemies challenges to us to confront the hatreds that cripple society and threaten to destroy the global village. A central question behind this premise, is what kind of society we are created, and destined, to be? If we are a society that is based on vengeance, we are doomed to cycles of violence and injustice in which the victims and the perpetrators simply trade places throughout history. If, however, we choose to display the kind of "moral courage" required for true forgiveness that is coupled with justice, not only for the past, but also for the future, then reconciliation may become possible (De Gruchy 2002: 173).

In essence a political of forgiveness requires the prose of justice - the land must be returned to those from whom it was unjustly taken, the stronghold of white South Africans on the economy must be deconstructed and distributed, and social and political systems must be opened up for fair and equitable participation by all South Africans. Yet, a political forgiveness requires something even more radical than this - it also requires the poetics of agape. Some political actors would have us believe that the solution to our challenges in South Africa are purely transactional, they are only political. If the land is returned, the economy is transformed, and we transform our social and political life to mitigate the legacy of white privilege in South Africa, then utopia will have been realised in the land. Such a narrow transactional view of forgiveness is not only theoretically inadequate, it also does not address the severity of black pain and white culpability in relation to apartheid. A merely transactional view of forgiveness is also too 'thin' since it errs by collapsing itself completely into the structural, while 
missing the importance of the ontological. It is a politics that is devoid of grace.

The philosopher, Paul Ricoeur, argues that it is precisely the fact that true forgiveness is transactionally impossible, that makes the act of impossible (and exceptional) grace both possible and necessary in forgiveness (cf., Ricoeur 2000: 31-36, 2004: 6-18). A purely structural approach to forgiveness, one that is tied to vengeance, runs the risk of becoming trapped in an unchangeable past. However, when a structural (political) approach to forgiveness is coupled with an ontological understanding of forgiveness the possibility of a liberated future is unlocked. "The unfulfilled future of the past forms perhaps the richest part of tradition. The liberation of this unfulfilled future of the past is the major benefit that we can expect from the crossing of memories and the exchange of narratives." (Ricoeur \& Brennan 1995: 8). De Gruchy echoes such a sentiment when he says that what is essential in authentic forgiveness is that the wounds of those who have suffered are truly healed, while at the same time, no new wounds are inflicted. In other words, "forgiveness enables those who forgive to overcome their bitterness and redeem their future, and those who sinned against them to recover their own humanity." (De Gruchy 2002: 174, 177).

Memory plays an important role in the dialogue between the structural and the ontological, between prose and poetry. In discussing the intention of the TRC and its amnesty process, De Gruchy write that, "Amnesty, as many have said, does not mean amnesia." (De Gruchy 2002: 178). The ontological call for forgiveness does not require that we forget. Quite the opposite; first, ontological forgiveness, according to De Gruchy, calls us to remember in whose image we are created. We bear the image of the God who is love and grace and also justice. In an ontological sense we are to remember who we are by remembering who God is. Our Christian life is structured according to sacraments of forgiveness - baptism, Eucharist, confession and penance (De Gruchy 2002: 5). These 'means of grace' call to remembrance in the common life of the Church that we are to be a sacrament to the world that embodies the new humanity for which Jesus died and rose again. As De Gruchy notes, when we understand our theological tradition in this way, we can see how our beliefs and convictions (the ontological commitments) shape our social and political lives (the structural elements) (De Gruchy 2002: 4). It was precisely to this 
aim that De Gruchy wrote his book, Liberating Reformed Theology (De Gruchy 1991). He writes that, "forgiveness also implies remembering the past in ways that heal relationships, build community and thus anticipate a new future." (De Gruchy 2002: 178). In this quotation we can see how De Gruchy's dialogical approach to faith and life brings theological conviction into conversation with lived reality. It is not stuck in the past, it is not static, it operates within the horizon of an eschatological hope. How we deal with the past, in our present, has a bearing on our future. It is for this reason that forgiveness matters so much! Inadequate conceptions and processes of forgiveness can become a stumbling block that can hinder the movement from a painful past towards a promised future. It is the belief in the hope that lies ahead, an ontological hope that stems from belief in a God who is both just and forgiving, that allows Christians to engage the current lived reality, the structural constraints of history and memory and politics and economics, in a forgiving manner. In this sense, political forgiveness is "a risk taken on the basis of mature insight and political acumen and one that displays moral courage" (De Gruchy 2002: 173). Political forgiveness reframes what we remember about the past, by transforming the present, so that what we will remember in the future is both structurally just, and ontologically true.

\section{Conclusion}

In this essay we sought to perform two tasks. First, to show how John de Gruchy's dialogical theology presents opportunities for bringing Christian belief (ontological commitments) to bear upon contextual realities (structural concerns in historical and contemporary life). In this process we saw how John de Gruchy engaged his own, and his tradition's faith commitments in relation to a number of challenges and opportunities in history and society. The result of this dialogue is a nuanced, textured, and robust theology that takes God's work in history and creation seriously. Second, we focussed upon his notion of "political forgiveness" to illustrate the richness and promise of such an approach. We saw that certain understandings of forgiveness remain rightly contested in contemporary South African theologies. In particular, it was those approaches to forgiveness that failed to bring the ontological into conversation with the structural that were most commonly considered insufficient since they did 
not adequately address the requirement for justice as an aspect of Christian forgiveness. Yet, at the same time it was argued that Christians should not give up on forgiveness in favour of mere political solutions. A purely structural approach to South Africa's history and current lived reality is also inadequate to address the stumbling blocks that prohibit the journey towards reconciliation. Rather, what is required is what John de Gruchy aptly characterises as a "political forgiveness" (De Gruchy 2002: 173) since it holds possibilities both for the setting right historical injustice, and also for ushering in "God's promise of new life, new worlds, new possibilities" (De Gruchy 2002: 213).

\section{Bibliography}

Alles het niet kom wôd deur Nathan Trantraal: ' $n$ resensie. 2017. [Online], Available: http://www.litnet.co.za/alles-het-niet-kom-wod-deurnathan-trantraal-n-resensie/ [2018, April 22].

Baker, A 2019. What South Africa can teach us as worldwide economic inequality grows. Time. South Africa:1-11.

Brubaker, R 2017. Between nationalism and civilizationism: the European populist moment in comparative perspective. Ethnic and Racial Studies 40(8):1191-1226.

Bundy, C 2000. The Beast of the Past: History and the TRC. After the TRC: Reflections on truth and reconciliation in South Africa. 9-20.

Cherkaoui, M 2017. Trump's Death Kiss on the Middle East Peace Process.

Clements, K 2016. De Gruchy, John W. I Have Come a Long Way. Cape Town: Lux Verbi 2015. The Ecumenical Review 68(1):153-155.

Dyrness, WA \& Kärkkäinen, V-M Eds. 2009. Global Dictionary of Theology: A Resource for the Worldwide Church. Downers Grove, IL: InterVarsity Press.

Everett, WJ \& De Gruchy, JW 2014. Sawdust and Soul: A Conversation about Woodworking and Spirituality. Wipf and Stock Publishers. 
Fekete, L 2016. Hungary: power, punishment and the "Christian-national idea”. Race \& Class 57(4):39-53.

Forster, D 2016. Why the "loss of faith" in heroes like Mandela may not be such a bad thing. Sunday Times (Johannesburg). 3 November. [Online], Available: http://www.timeslive.co.za/sundaytimes/ stnews/2016/09/29/Why-the-'loss-of-faith'-in-heroes-like-Mandelamay-not-be-such-a-bad-thing [Accessed: 2016, November 03].

Forster, D 2019a. New directions in evangelical Christianities. Theology. 122(4):267-275.

Forster, DA 2011. Empire, Economics and Apathy: A theological reflection on suffering as a result of HIV/AIDS. In LR Withrow (ed.). Lanham, MD: Lexington Books. Alienation and connection: Suffering in a global age. 71-96.

Forster, DA 2015. What hope is there for South Africa? A public theological reflection on the role of the church as a bearer of hope for the future. HTS Teologiese Studies / Theological Studies. 71(1):1-10.

Forster, DA 2018. Translation and a politics of forgiveness in South Africa? What black Christians believe, and white Christians do not seem to understand. Stellenbosch Theological Journal. 14(2):77-94.

Forster, DA 2019b. State Theology and Political Populism? A Kairos Critique of Religious Populism in South Africa. Oxford Journal of Church and State. csz031:1-18.

Forster, D \& Pondani, S 2019. Why South Africans are prone to falling for charlatans in the church. The Conversation (Johannesburg). 10 March. [Online]. Available: http://theconversation.com/why-south-africansare-prone-to-falling-for-charlatans-in-the-church-112879 [Accessed: 2019, March 10].

General Household Survey 2013. 2014. (Statistical Information 1). Pretoria, South Africa: Statistics South Africa. [Online], Available: http://www. statssa.gov.za/publications/P0318/P03182013.pdf [Accessed: 2015, June 11]. 
Gobodo-Madikizela, P \& Merwe, CVD 2009. Memory, Narrative and Forgiveness: Perspectives on the Unfinished Journeys of the Past.

Cambridge: Cambridge Scholars Publishing.

De Gruchy, JW Ed. 1999. Cambridge Companion to Dietrich Bonhoeffer. Cambridge: Cambridge University Press.

De Gruchy, JW 1984. Bonhoeffer and South Africa: Theology in Dialogue. Grand Rapids, MI: WB Eerdmans Publishing Company.

De Gruchy, JW 1986. Cry justice! Prayers, meditations, and readings from South Africa. Maryknoll, NY: Orbis Books.

De Gruchy, JW 1988. The struggle for justice and the ministry of reconciliation. In K. Nürnberger \& J. Took (eds.). Cape Town: Methodist Publishing House and Book Depot The Cost of Reconciliation in South Africa. 166-180.

De Gruchy, JW 1991. Liberating Reformed Theology : A South African Contribution to an Ecumenical Debate. Grand Rapids, MI: Wm. B Eerdmans Publishing Company. [Online]. Available: https://www. thriftbooks.com/w/liberating-reformed-theology-a-south-africancontribution-to-an-ecumenical-debate_john-w-de-gruchy/1781197/\#is bn $=0802805361$ \&idiq $=18298161$.

De Gruchy, JW 1997. Bonhoeffer for a New Day: Theology in a Time of Transition: Papers Presented at the Seventh International Bonhoeffer Congress, Cape Town, 1996. Grand Rapids, MI: William B Eerdmans Publishing Company.

De Gruchy, JW 2001. Christianity, Art and Transformation: Theological Aesthetics in the Struggle for Justice. Cambridge: Cambridge University Press.

De Gruchy, JW 2002. Reconciliation: Restoring Justice. London: Fortress Press.

De Gruchy, JW 2005a. The Church Struggle in South Africa. Twenty-fifth anniversary ed., 1st Fortress Press ed ed. Minneapolis: Fortress Press.

De Gruchy, JW 2005b. Daring trusting spirit: Bonhoeffer's friend Eberhard Bethge. London: SCM Press. 
De Gruchy, JW 2006. Confessions of a Christian Humanist. Philadelphia: Fortress Press.

De Gruchy, JW 2011a. Icons as a Means of Grace. Lux Verbi.BM.

De Gruchy, JW 2011b. The Humanist Imperative in South Africa. Stellenbosch: AFRICAN SUN MeDIA.

De Gruchy, JW 2013a. Led into mystery: faith seeking answers in life and death. London: SCM Press.

De Gruchy, JW 2013b. John Calvin: Christian Humanist and Evangelical Reformer. Eugene, OR: Wipf and Stock Publishers.

De Gruchy, JW 2014. A theological odyssey: My life in writing. Stellenbosch: AFRICAN SUN MeDIA.

De Gruchy, JW 2016. I Have Come a Long Way. Wipf and Stock Publishers.

De Gruchy, JW \& Villa-Vicencio, C 1983. Apartheid is a Heresy. Grand Rapids, MI: Eerdmans Pub Co.

De Gruchy, JW \& Villa-Vicencio, C 1985. Resistance and Hope South African Essays in Honour of Beyers Naudé. D. Philip.

Hofmeyr, JH \& Govender, R 2015. SA Reconciliation Barometer 2015: National Reconciliation, Race Relations, and Social Inclusion. Cape Town: Institute for Justice and Reconciliation. [Online]. Available: http://www.ijr.org.za/uploads/IJR_SARB_2015_WEB_002.pdf.

Holness, L \& Wüstenberg, RK Eds. 2002. Theology in Dialogue: The Impact of the Arts, Humanities, and Science on Contemporary Religious Thought : Essays in Honour of John $W$ de Gruchy. Cape Town: David Philip Publishers.

Koopman, N 2003. Some Comments on Public Theology Today. Journal of Theology for Southern Africa; Scottsville. (117):3-19.

Kotzé, H 2016. Shared values in South Africa? A selection of value orientations in the field of personal ethics. Scriptura. 75:437-448. 
Kotzé, H \& Garcia-Rivero, C 2017. Institutions, crises, and political confidence in seven contemporary democracies. An elite-mass analysis. Journal of Public Affairs. 17(1-2):1-17.

Lugo, L \& Cooperman, A 2010. Tolerance and tension: Islam and Christianity in sub-Saharan Africa. Washington, DC, Pew Research Centre. 1-147.

Mbembe, A 2015. Achille Mbembe on The State of South African Political Life. [Online]. Available: http://africasacountry.com/2015/09/achillembembe-on-the-state-of-south-african-politics/ [Accessed: 2016, January 02].

Migliore, DL 2004. Faith Seeking Understanding: An Introduction to Christian Theology. Grand Rapids, MI: Wm. B. Eerdmans Publishing.

Peires, J 2009. Agony and Ecstasy at the End of the Rainbow. South African Historical Journal. 61(1):178-186.

Ricoeur, P 2000. Can forgiveness heal? In HJ Opdebeeck (ed.). Leuven: Peeters The Foundation and Application of Moral Philosophy: Ricoeur's Ethical Order. 31-36.

Ricoeur, P 2004. The difficulty to forgive. In M Junker-Kenny \& P. Kenny (eds.). Münster: LIT Verlag Memory, Narrativity, Self and the Challenge to Think God: The reception with Theology of the Recent work of Paul Ricoeur. 6-18.

Ricoeur, P \& Brennan, E 1995. Reflections on a new ethos for Europe. Philosophy \& social criticism. 21(5-6):3-13.

Schoeman, WJ 2017. South African religious demography: The 2013 General Household Survey. HTS Teologiese Studies / Theological Studies. 73(2):1-7.

Shore, M 2016. Religion and Conflict Resolution: Christianity and South Africa's Truth and Reconciliation Commission. Routledge.

Shriver, DW 1995. An Ethic for Enemies: Forgiveness in Politics. Oxford: Oxford University Press.

Smit, D 2007. Notions of the public and doing theology. International Journal of Public Theology. 1(3):431-454. 
Steyn, M 2001. Whiteness in the Rainbow: Experiencing the loss of privilege in the New South Africa. In CV Hamilton, L Huntley, N Alexander, ASA Guimaræes, \& WJ Boulder (eds.). London: Lynne Rienner Publishers Beyond Racism: Race and Inequality in Brazil, South Africa, and the United States. 85-103.

Tartakoff, LY 2012. Religion, Nationalism, History, and Politics in Hungary's New Constitution. Society. 49(4):360-366.

Terreblanche, SJ 2002. A History of Inequality in South Africa, 1652-2002. Pietermaritzburg: University of Natal Press.

Trantraal, N 2017. Alles het niet kom wôd: 'n digbundel. Eerste uitgawe ed. Kaapstad: Kwela.

Tutu, D 2012. No Future Without Forgiveness. New York, NY: Random House.

"UCT's De Gruchy honoured". 2004. [Online]. Available: http://www. news.uct.ac.za/article/-2004-05-03-ucts-de-gruchy-honoured [Accessed: 2019, August 09].

Union Theological Seminary. 2016. Cornel West on a Healthy Atheism. Union Theological Seminary, New York. [Online]. Available: https:// www.youtube.com/watch?time_continue $=87 \& v=L W I s a w V j v W I$ [Accessed: 2016, September 21].

Van der Merwe, H \& Chapman, AR 2008. Truth and reconciliation in South Africa: Did the TRC deliver? University of Pennsylvania Press.

Van Wyk, I 2014. The Universal Church of the Kingdom of God in South Africa: A Church of Strangers. Vol. 47. Cambridge University Press.

Vincent, L 2011. Seducing the people: Populism and the challenge to democracy in South Africa. Journal of Contemporary African Studies. 29(1):1-14.

Vosloo, R 2015a. Difficult Forgiveness? Engaging Paul Ricoeur on Public Forgiveness within the Context of Social Change in South Africa. International Journal of Public Theology. 9(3):360-378. 
Vosloo, R 2015b. Between the Prose of Justice and the Poetics of Love? Reading Ricœur on Mutual Recognition in the Light of Harmful Strategies of "Othering”. Études Ricoeuriennes / Ricoeur Studies. 6(2).

Vosloo, RR 2012. Traumatic memory, representation and forgiveness: Some remarks in conversation with Antjie Krog's Country of my Skull. In die Skriflig. 46(1).

Walker, S 2019. Orbán deploys Christianity with a twist to tighten grip in Hungary. The Guardian. 14 July. [Online]. Available: https://www. theguardian.com/world/2019/jul/14/viktor-orban-budapest-hungarychristianity-with-a-twist [Accessed: 2019, August 10].

Winter, S \& Burchert, LT 2015. Value change in post-apartheid South Africa. South Africa: Konrad-Adenauer-Stiftung e.V. [Online]. Available: http://www.kas.de/wf/doc/kas_41566-1522-2-30. pdf?150609093459.

van Wyk, I 2019. Why “money” gospel followers aren't simply credulous dupes. The Conversation (Johannesburg). 21 February. [Online]. Available: http://theconversation.com/why-money-gospel-followersarent-simply-credulous-dupes-111838 [Accessed: 2019, March 07]. 